\title{
THE USE OF A MICROCONTROLLERS IN HYGROMETRIC MEASUREMENTS APPLICATION
}

\author{
Artur Bogdanowicz*1(D), Marcin Zacharewicz*2 (D), Jakub Król** \\ * Polish Naval Academy, Faculty of Mechanical and Electrical Engineering, Śmidowicza 69 Str., 81-127 \\ Gdynia, Poland; e-mail: a.bogdanowicz@amw.gdynia.pl, m.zacharewicz@amw.gdynia.pl; ORCID ID: \\ 10000-0002-5076-6675, 20000-0002-8294-873X \\ ** Graduate Polish Naval Academy, Faculty of Mechanical and Electrical Engineering, Śmidowicza 69 Str., \\ 81-127 Gdynia, Poland
}

\begin{abstract}
The article presents the possibility of using microcontroller systems as one of elements of a teaching position. The Arduino Mega system based on the ATMega 2560 microcontroller from the AVR family was used to build the station. At the beginning, a virtual hygrometer model was designed in the AUTOCAD program and then the air channels were made using 3D printing. After assembling the station, it was compared to a laboratory aspiration hygrometer. The analysis was presented in the final part of the article.
\end{abstract}

Keywords:

microcontroller system, hygrometer, laboratory station.

Research article

(C) 2020 Artur Bogdanowicz, Marcin Zacharewicz, Jakub Król This is an open access article licensed under the Creative Commons Attribution-NonCommercial-NoDerivatives 4.0 license (http://creativecommons.org/licenses/by-nc-nd/4.0/) 


\section{INTRODUCTION}

Already at the turn of the fifteenth and sixteenth centuries, attempts were made to study the change of water vapor content in the air. The first primitive hygrometers were based on the method of hygroscopic measurement, e.g. change in the weight of a woolen sphere absorbing moisture from the atmosphere. These studies contributed to the further development of this field, and other solutions and materials that absorb moisture have been sought $[2,4]$.

\section{MEASUREMENT OF AIR HUMIDITY USING A HYGROMETER}

The psychrometer is a device from the family of hygrometers. The simplest consists of two thermometers, one of which is surrounded by a fabric soaked with distilled water, and shows temperature of the wet thermometer. And the other is an ordinary thermometer indicating the ambient temperature [1].

The measurement in the psychrometric method depends on the state of saturation with the steam of the air flowing around the wet thermometer. The result of the difference in component pressures of the water vapor (air flowing around the wet thermometer) and the ambient air is the evaporation of water from the so-called hygroscopic. The tank with the thermometric liquid cools to the temperature corresponding to the cooling limit [1].

The psychometric difference is difference between indication of a dry and wet thermometer. It depends on the humidity of ambient air. The lower relative humidity, greater temperature difference. If the air is saturated, namely $\varphi=100 \%$, both thermometers will show the same temperature [1].

We use the Sprung formula for psychrometric calculations. It is based on heat taken from the atmosphere used to evaporate the water from wet bulb thermometer. This heat returns in the form of heat of evaporation of water into the air.

With the assumed conditions of heat exchange and free inflow of air mass, knowing the temperatures of thermometers $t_{s}$ dry air temperature) and $t_{m}$ (wet air temperature), we can determine the exact air humidity for $t_{s} \leq 323,15 \mathrm{~K}$, using the Sprung formula [1].

$$
\varphi=\frac{p_{p}}{p_{p s}^{\prime \prime}}=\frac{p_{p m}^{\prime \prime}-A\left(t_{s}-t_{m}\right) \cdot p_{b}}{p_{p s}^{\prime \prime}} \cdot 100 \%,
$$


where:

$$
A=\left(65+\frac{6.75}{w}\right) \cdot 10^{-5} \cdot K^{-1}
$$

A - psychrometric constant dependent on factors such as the type of gas, gas velocity around a container with thermometric liquid thermometer, wet bulb temperature. Psychrometer construction, dimensions and shape of a thermometric liquid container have a very big influence on the psychrometric constant [1].

The Assmann psychrometer is a device consisting of two dry and wet thermometers surrounded by cover (fig. 1). It is additionally equipped with a reservoir with thermometric liquid protection against influence of solar radiation and a fan that generates forced airflow at a speed $w$ of $2.5[\mathrm{~m} / \mathrm{s}]$ to $4.0[\mathrm{~m} / \mathrm{s}]$. This speed corresponds to the psychrometric constant $[1,7]$.

Measuring range: temperature from 273.15 [K] to 323.15 [K], relative humidity of air from 5 [\%] to 95 [\%]. If the temperature exceeds $t_{s}>323.15[\mathrm{~K}]$ then the accuracy decreases. This is due to a non-adiabatic humidification process [11].

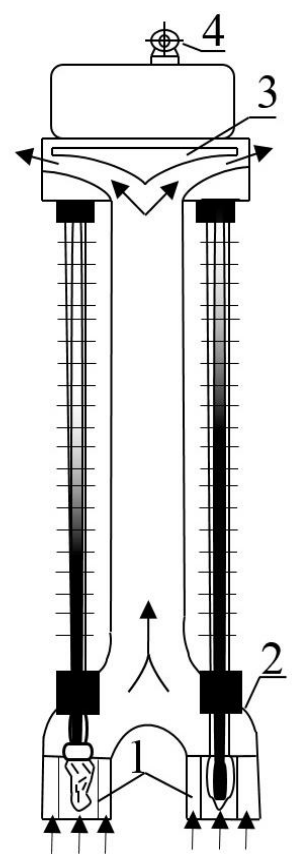

Fig. 1. The Assmann psychrometer [8]:

1 - wet thermometer, 2 - dry thermometer, 3 - screens, 4 - fan, 5 - fan drive 


\section{THE METHOD OF CALCULATING THE RELATIVE HUMIDITY}

The rapid development of microcontrollers was the reason that these systems are increasingly used in various projects, including those related to temperature measurement. Cheap electronic circuits can be used as replacements for expensive components. Projects have already been carried out in which infrared thermometers [5, 6] and microcontrollers [3] were used for hygroscopic measurements. Due to the fact that there is a gap in the availability of simple tools for hygroscopic measurements, authors decided to use DS18B20 digital thermometers for temperature measurement using the Arduino Mega microcontroller system with an LCD display.

\section{ASPIRATION PSYCHROMETER USING A MICROCONTROLLER SYSTEM}

The creation of microcontroller systems forced the appearance of ready devices using these systems. The development of IDE software and libraries has made programming of these electronic components much easier. One of the examples are Arduino systems, which in their design use microcontrollers from the AVR family. The Arduino Mega 2560 R3 was selected for the construction of the psychrometer. The board uses the AVR ATmega 2560 microcontroller. Fig. 2 shows the MEGA2560 R3 board.

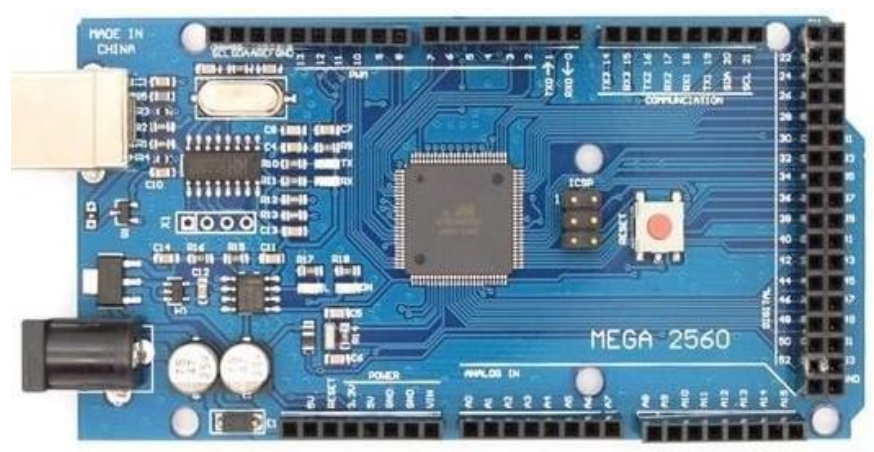

Fig. 2. MEGA2560 R3 [9]

Dallas DS18B20 digital thermometers were used to measure the temperature of dry and wet parts. For communication, they use the 1-Wire protocol. Fig. 3 shows the temperature sensor DS18B20. DC electrical characteristics shows tab. 1. 


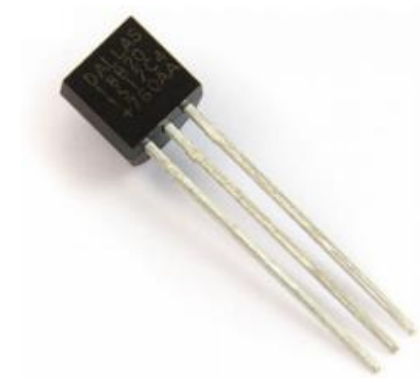

Fig. 3. Digital temperature sensor DS18B20 [10]

Tab. 1. DC electrical characteristics [10]

\begin{tabular}{|c|c|c|}
\hline Parameter & \multicolumn{2}{|c|}{ Value } \\
\hline Supply voltage & \multicolumn{2}{|c|}{+3.0 to $5.5 \mathrm{~V}$} \\
\hline Thermometer error & $\begin{array}{l}-10^{\circ} \mathrm{C} \text { to }+85^{\circ} \mathrm{C} \\
-10^{\circ} \mathrm{C} \text { to }+85^{\circ} \mathrm{C} \\
-55^{\circ} \mathrm{C} \text { to }+125^{\circ} \mathrm{C}\end{array}$ & $\begin{array}{c} \pm 0.5^{\circ} \mathrm{C} \\
\pm 1^{\circ} \mathrm{C} \\
\pm 2^{\circ} \mathrm{C}\end{array}$ \\
\hline Input logic-low & \multicolumn{2}{|c|}{-0.3 to $+0.8 \mathrm{~V}$} \\
\hline Input logic-high & \multicolumn{2}{|c|}{$+3.0 \mathrm{~V}$} \\
\hline Standby current & \multicolumn{2}{|c|}{$750 \mathrm{nA}$} \\
\hline Active current & \multicolumn{2}{|c|}{$1.5 \mathrm{~mA}$} \\
\hline Drift & \multicolumn{2}{|c|}{ $\pm 0.2^{\circ} \mathrm{C}$} \\
\hline
\end{tabular}

To connect sensors of the Arduino board, an intermediate plate was designed in the EAGLE program, on which the digital display, signal diodes, control buttons, pins for 1-Wire communication and a system for controlling the speed of the fan were placed. The diagram of the intermediate plate connections is shown in fig. 4. The plate was made using the thermal transfer method and etched with sodium persulfate.

To make the body of the psychrometer on which the fan was installed, 3D printer was used. For this purpose, a virtual model of the psychrometer was designed in AutoCad program and later the G code was constructed on it. 3D printing was carried out on an IPrus printer. The stand, on which the air flow ducts together with the fan were installed, was made of larch wood. Fig. 5 shows the visualization of the hygrometer model in the AutoCad program.

The system was programmed in the Arduino IDEand mounted on the platform. Fig. 6 shows the complete aspiration psychrometer with the control and measurement system. 

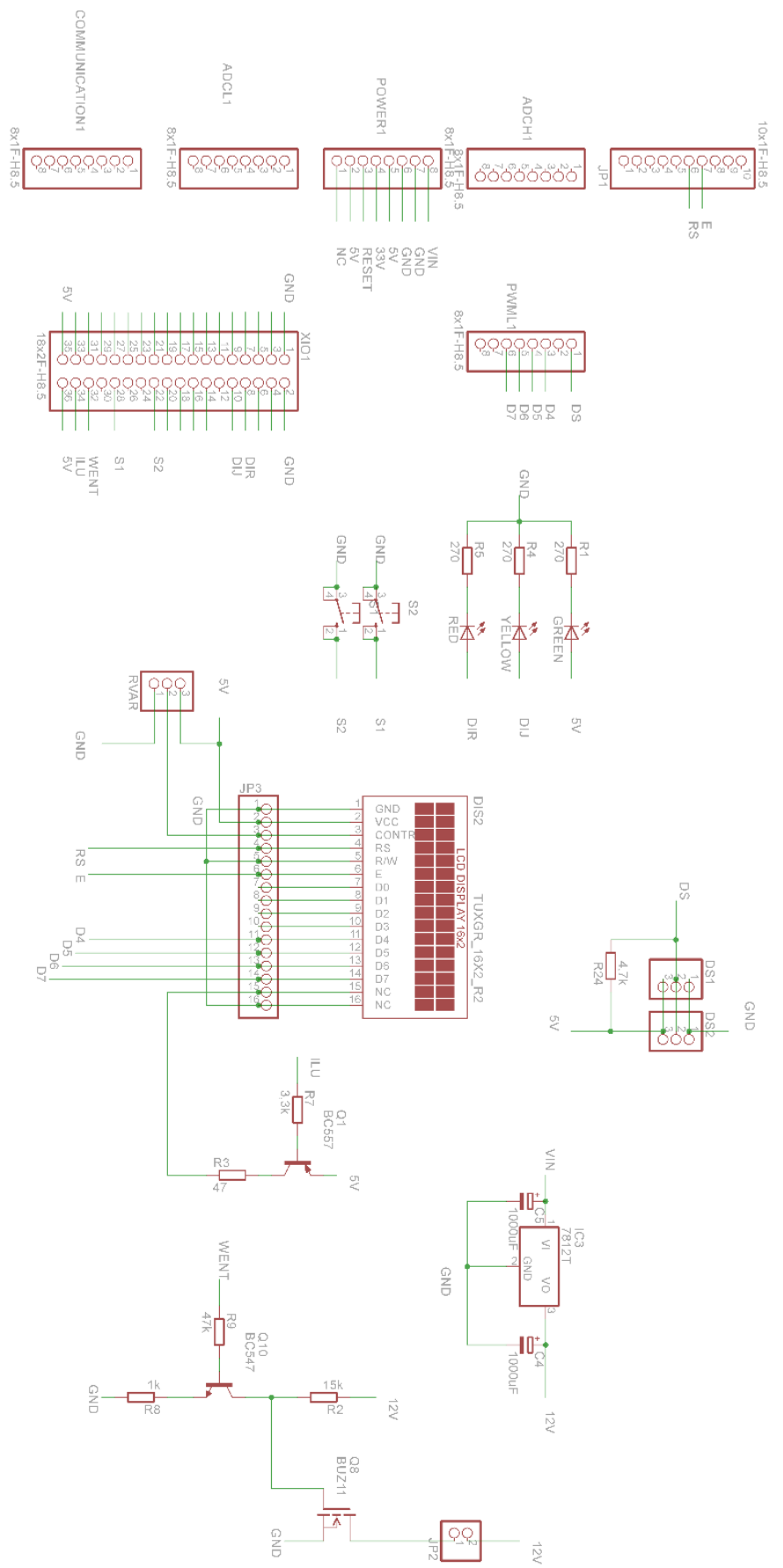

Fig. 4. Diagram of connections in the EAGLE program 


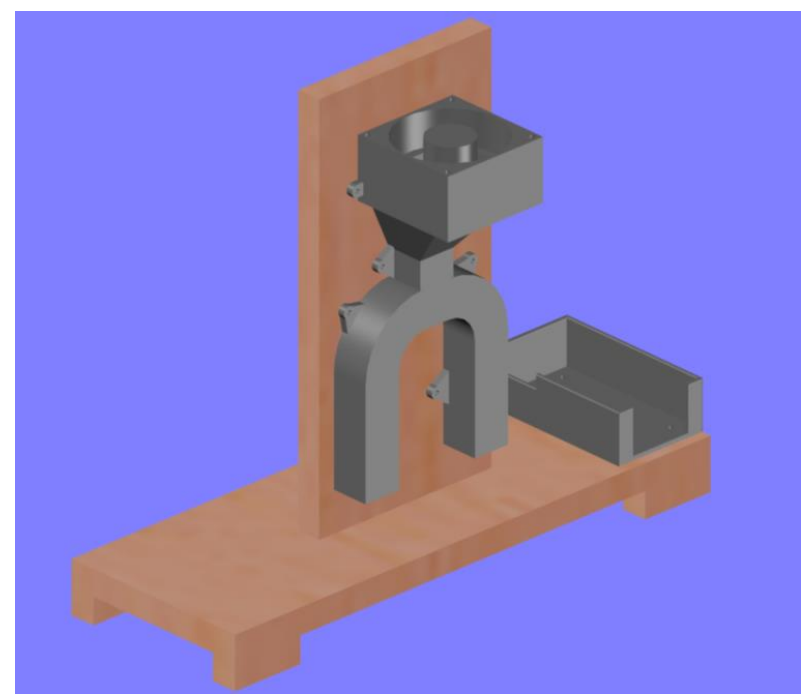

Fig. 5. Visualization of the hygrometer in the AutoCad program

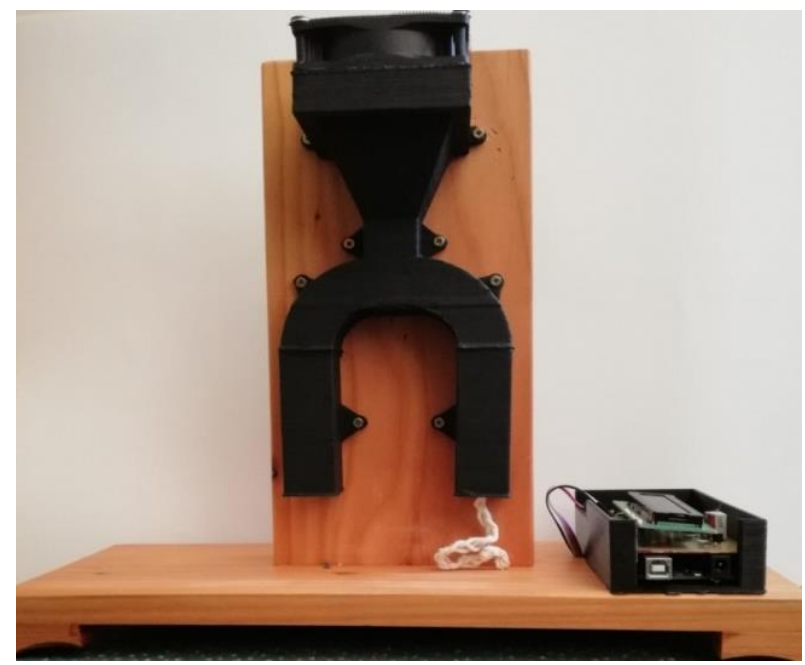

Fig. 6. Aspiration psychrometer based on digital temperature measurement

\section{RESEARCH AND CALCULATION}

The designed aspiration psychrometer was compared with a psychrometer recognized as the model company of 'WSZ Kraków'. The test consisted in measuring the temperature of the 'wet' and 'dry' thermometers of both psychrometers. Eight 
measurements were carried out - four under present atmospheric conditions and four using steam produced by an electric kettle. After analyzing the measurement results, the test was presented using tables and diagrams.

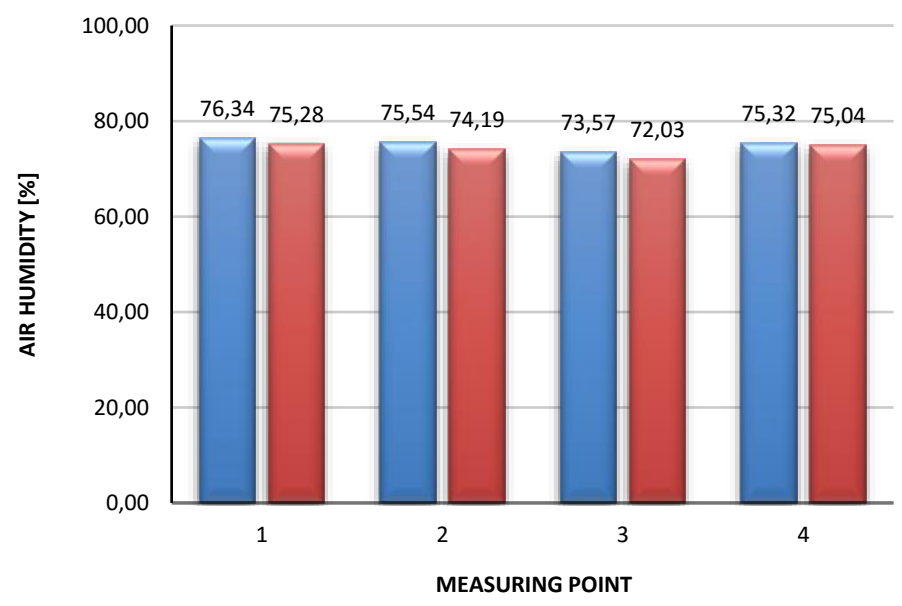

Fig. 7. Comparison of relative humidity under atmospheric conditions: blue - standard psychrometer, red - digital psychrometer

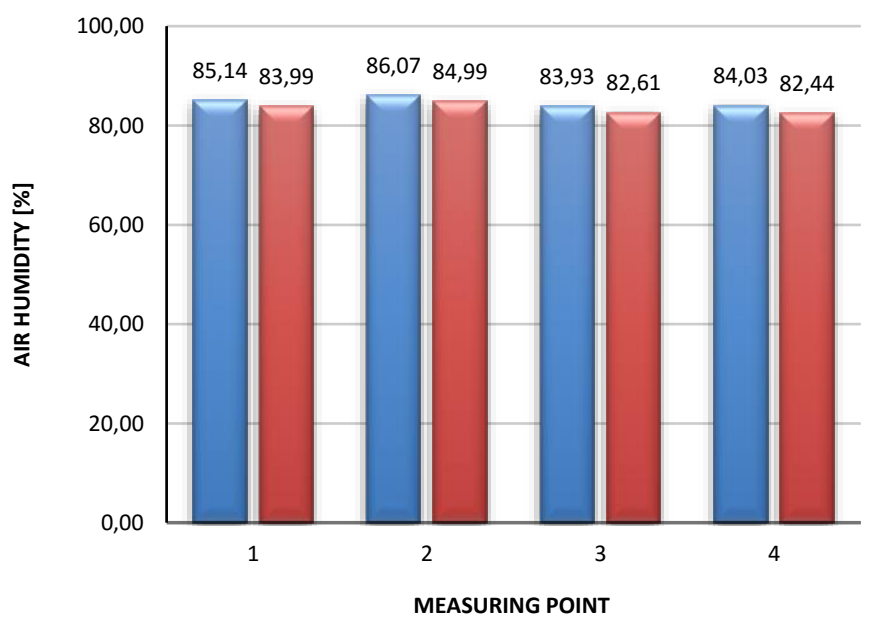

Fig. 8. Comparison of relative humidity in conditions with forced humidity: blue - standard psychrometer, red - digital psychrometer 


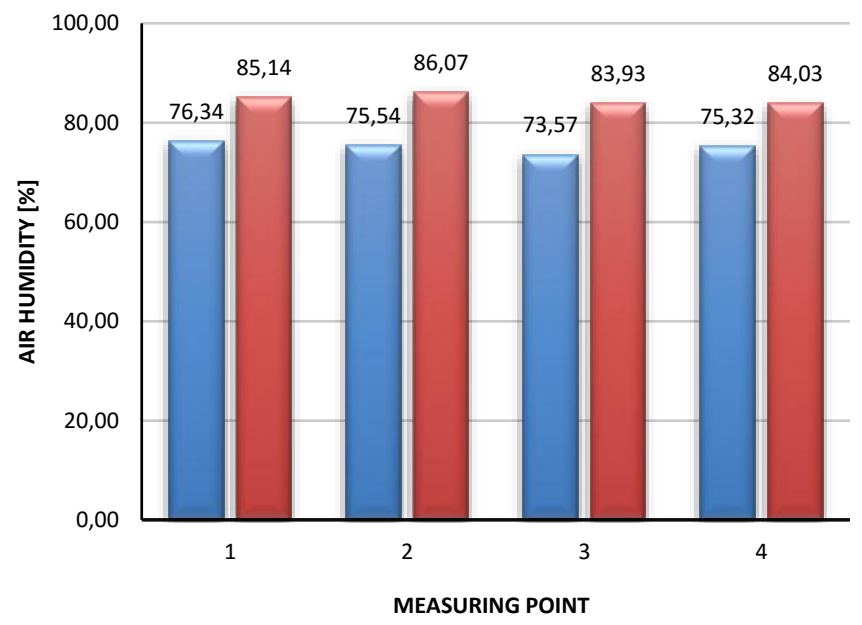

Fig. 9. Comparison of relative humidity under different conditions for the reference psychrometer: blue - standard psychrometer, red — digital psychrometer

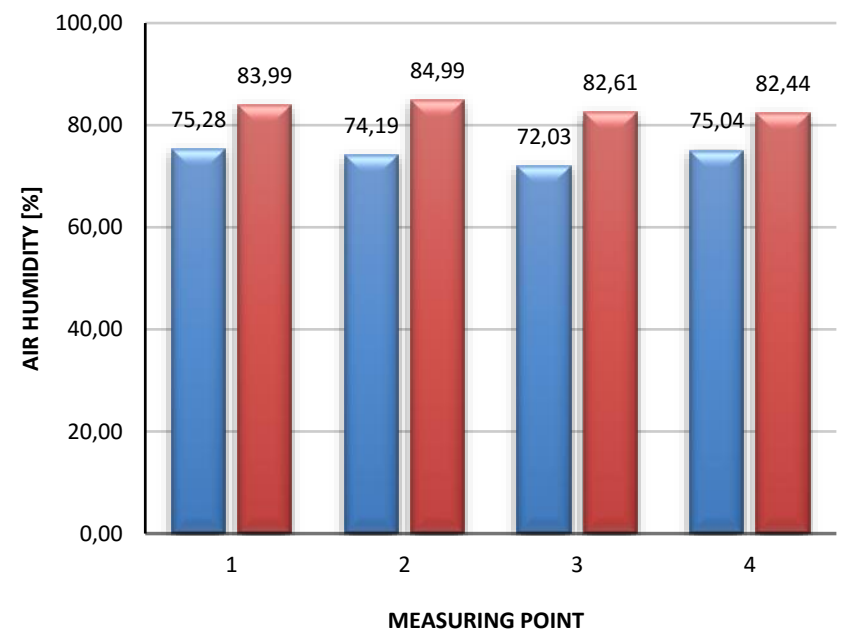

Fig. 10. Comparison of relative humidity in different conditions for digital psychrometer: blue - standard psychrometer, red — digital psychrometer

\section{CONCLUSIONS}

The goal of the project was to build an aspiration hygrometer based on digital temperature measurement. The measurements showed a relative humidity error 
not exceeding 2 [\%], therefore a hygrometer for lab exercises can be used as a didactic stand.

The temperature results of both psychrometers, which were obtained during measurements under atmospheric conditions, were similar to each other. The relative values calculated on their basis differed from 0.16 [\%] to 1.55 [\%] depending on the measurement points. Therefore, an arithmetic mean was derived from them, which amounted to 0.69 [\%]. This is a favorable result for the digital psychrometer compared to its model counterpart.

In summary, microcontroller systems can be used to build teaching positions. Together with digital sensors that measure to two decimal places, they are an alternative to this type of device.

The position in the future can be equipped with a sensor measuring atmospheric pressure. This would allow a more accurate reading of relative humidity and would improve the work of this device.

\section{REFERENCES}

[1] Bratek T., Kapitaniak A., Kulesza J. et al., Pomiary cieplne, Part 1, Publ. WNT, Warszawa 19931995 [Thermal measurements — available in Polish].

[2] Górski J., Matejak M., Zarys historii pomiaru wilgotności powietrza, 'Muzealnictwo', 1998, No. 40, pp. 145-150 [An outline of the history of measuring humidity - available in Polish].

[3] Komor G., Nowicki M., Biś K., Szewczyk R., Microprocessor based assmann psychrometer, 'Advances in Intelligent Systems and Computing', 2018, Vol. 743, pp. 628-634, DOI: 10.1007/9783-319-77179-3_59.

[4] Kozakiewicz P., Matejak M., Higrometr - historia pomiaru wilgotności względnej powietrza, Publ. SGGW, Warszawa 1998 [History of relative humidity measurement — available in Polish].

[5] Lee C., Wang Y. J., Psychrometer based on a contactless infrared thermometer with a predictive model for water evaporation, 'Biosystems Engineering', 2017, Vol 160, pp. 84-94, DOI: 10.1016/j.biosystemseng.2017.05.010.

[6] Li C., Chung J. Y., A novel design of psychrometer based on a single-packaged contactless infrared thermometer, 'Journal of Taiwan Agricultural Engineering', 2017.

[7] Milewska I., Dobrzański T. (ed.), Mechanik — poradnik techniczny, Part 3, Publ. PWT, Warszawa 1960 [Mechanic - technical guide - available in Polish].

[8] Pomiar wilgotności powietrza, [online], [Air humidity measurement - available in Polish], http://ktc.zut.edu.pl/fileadmin/dydaktyka/instrukcje/cwiczenie_9.pdf [access 03.03.2020].

[9] https://www.arduino.cc/ [access 03.03.2020].

[10] https://www.maximintegrated.com/en.html [access 03.03.2020].

[11] http://www.kseiuos.agh.edu.pl/dla_studentow/metrologia_cieplna/ [access 03.03.2020]. 


\section{WYKORZYSTANIE MIKROKONTROLERA W BUDOWIE HIGROMETRU ASPIRACYJNEGO}

\section{STRESZCZENIE}

W artykule przedstawiono możliwość wykorzystania systemów mikrokontrolerów jako jednego z elementów stanowiska dydaktycznego. Do jego budowy wykorzystano system Arduino Mega oparty na mikrokontrolerze ATMega 2560 z rodziny AVR. W początkowej fazie za pomocą programu AUTOCAD opracowano model higrometru, a następnie wykonano go przy użyciu druku 3D. Po zmontowaniu higrometru przeprowadzono badania $\mathrm{z}$ wykorzystaniem opracowanego higrometru oraz higrometru będącego na stanie laboratorium eksploatacji siłowni okrętowych. Badania miały na celu ocenę dokładności opracowanego higrometru. Wyniki badań przedstawiono w końcowej części artykułu.

\section{Słowa kluczowe:}

mikrokontroler, higrometr, stanowisko dydaktyczne.

Article history

Received: $\quad 04.03 .2020$

Reviewed: 23.03.2020

Revised: $\quad 28.04 .2020$

Accepted: $\quad 29.04 .2020$ 